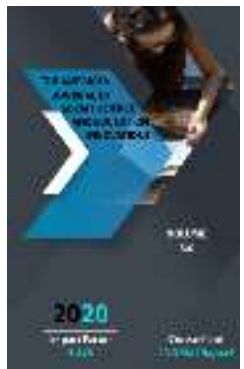

\section{Economic Significance And Theoretical Fundamentals Of Sustainable Development Of Fruit And Vegetable Growth}

\author{
Khasanov Sobir Saydivalievich \\ Independent Researcher Of Tashkent State University Of Law, Uzbekistan
}

Journal Website: http://usajournalshub.c om/index,php/tajssei

Copyright: Original content from this work may be used under the terms of the creative commons attributes 4.0 licence.

\title{
ABSTRACT
}

In the current complex socio-economic and environmental conditions, the article provides for the growing needs of the population, the full and effective use of our domestic potential to replace imported fruits and vegetables, to solve these problems by modernizing and reforming agriculture. Development issues were discussed.

\section{KEYWORDS}

Agriculture, food security, fruits and vegetables, exports, economic reforms, transport and logistics.

\section{INTRODUCTION}

After the independence of our country, great attention is paid to the sustainable development of fruit and vegetable growing. The population of the republic is mainly provided with domestically grown agricultural and food products. The formation of market relations in the fruit and vegetable sector of Uzbekistan has its own characteristics, characterized by the complexity of the ongoing socio-economic changes and the dependence 
on supply and demand as a result of today's global changes.

This requires the rational and efficient use of existing natural and economic potential due to the limited production resources in the transition to market relations, increasing the volume of products, improving quality, reducing the cost of production by increasing labor productivity.

Sustainable development of the fruit and vegetable sector through modernization and reform of agriculture requires consideration and solution of a number of problems:

- First, modernization and renewal of the fruit and vegetable sector, development and implementation of measures to ensure the competitiveness of products that give a strong impetus to the sustainable development of the industry;

- Secondly, to ensure food security as a result of increasing dependence of the world consumer market on imports, to improve the mechanism of state support and management of the agricultural sector;

- Thirdly, due to the growing shortage of water resources from year to year, limited access to irrigated land, special attention should be paid to the use of advanced irrigation methods, in particular, the widespread introduction of drip irrigation;

- Fourth, the use of existing scientific and innovative opportunities through in-depth indicates the priority of radical reform and rapid development of the industry.

The essence of the ongoing economic reforms for the sustainable development of fruit and vegetables is determined by:

In economic terms, agriculture is an integral part of the country's economy, with fruit and vegetables accounting for $32.2 \%$ of total agricultural production. The fruit and vegetable sector is one of the main incomes of analysis of the economic and technological, legal and other opportunities and achievements of farmers and agricultural enterprises among the factors affecting the sustainable development of fruit and vegetable growing;

- Fifth, the most important task today is to develop and adopt programs to replace the imported fruits and vegetables in order to meet the needs of the population through the full and effective use of our domestic potential.

Given the study of problems in improving the strategy of sustainable development of fruit and vegetables in the current complex socioeconomic and environmental conditions, it is important to study the theoretical and methodological aspects of sustainable institutional change.

Therefore, the reform of the fruit and vegetable sector is one of the priorities of economic reforms in the country. From the first years of independence, the President and the Government of the Republic of Uzbekistan began radical economic reforms in agriculture and paid great attention to the development of fruit and vegetable growing as a priority in the transition to market relations. The fact that a significant part of the country's foreign exchange earnings is received through the sale of fruits and vegetables in foreign markets also

the population in rural areas, in addition, fruit and vegetable products play a key role in the country's agricultural exports;

in the social sphere - the effectiveness of sustainable development of fruit and vegetable production has a direct impact not only on the living standards of the population living in rural areas, but also on the well-being of the entire population of the country; 
In the political sphere, radical reform of fruit and vegetable growing and its effectiveness will ensure food security, which will be reflected in the positive results of economic reforms in all processes of development of the new Uzbekistan and will reflect the increase in living standards.
Fruit and vegetable growing, one of the main sectors of agriculture, accounted for $8.7 \%$ of the country's GDP in 2019. Therefore, the state of this industry has a direct impact on the development of a number of industries.

Fruit and vegetable products at the end of 2019 information on cultivation.

\begin{tabular}{|c|c|c|c|c|}
\hline Potato & Vegetables & Kaleyard & $\begin{array}{l}\text { Fruits and } \\
\text { berries }\end{array}$ & Grapes \\
\hline $\begin{array}{l}\text { 2950,9 thousand } \\
\text { t.. }\end{array}$ & $\begin{array}{l}9945,5 \text { thousand } \\
\text { t. }\end{array}$ & $\begin{array}{l}\text { 1922,2 thousand } \\
\text { t. }\end{array}$ & $\begin{array}{l}2739,6 \text { thousand } \\
\text { t. }\end{array}$ & $\begin{array}{l}1595,2 \text { thousand } \\
\text { t. }\end{array}$ \\
\hline $\begin{array}{l}101,3 \% \\
\text { (growth rate) }\end{array}$ & $\begin{array}{l}101,9 \% \\
\text { (growth rate) }\end{array}$ & $\begin{array}{l}104,6 \% \\
\text { (growth rate) }\end{array}$ & $\begin{array}{l}101,2 \% \\
\text { (growth rate) }\end{array}$ & $\begin{array}{l}100,3 \quad \% \\
\text { (growth rate) }\end{array}$ \\
\hline
\end{tabular}

In order to support the fruit and vegetable sector, first of all, serious positive changes must be made in the overall economy, including industry.

Large-scale financial resources are needed to accelerate the development of the fruit and vegetable sector. These funds can be generated domestically or through borrowing from foreign countries and international financial institutions. In many countries of the world, even in the most developed countries, agriculture is unprofitable, so the sector is constantly supported by the state.

As the President of the Republic of Uzbekistan Sh.Mirziyoyev noted: "Today, only $15 \%$ of fruits and vegetables grown in our country are processed and $8 \%$ are exported. Especially in Syrdarya, Jizzakh, Khorezm, Kashkadarya and Tashkent regions, these figures remain low. Is the export of 860,000 tons or $\$ 620$ million worth of fruits and vegetables this year in line with our opportunities and potential? No, of course not! Based on the experience of developed countries, there are no techniques for processing orchards and vineyards, sowing and harvesting vegetable and potato seeds, fuel and lubricants, mineral fertilizers, seed supply, disease and pest control are not organized at the required level. This is also true"[1].

\section{About some types of exported products Information from the State Statistics Committee}

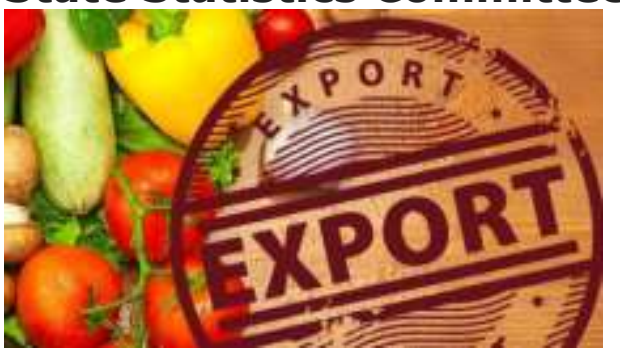

In recent years, many decisions have been made in the country to develop the scientific base of agriculture in line with modern requirements. A network of research institutes, experimental stations, and bases has been developed. Higher and secondary 


\begin{tabular}{|l|l|l|}
\hline Product name & $\begin{array}{l}\text { MIn. } \\
\text { USD }\end{array}$ & $\begin{array}{l}\text { compared } \\
\text { to 2018,\% }\end{array}$ \\
\hline $\begin{array}{l}\text { fruits and } \\
\text { berries }\end{array}$ & 658,1 & 116,1 \\
\hline vegetables & 542,4 & 170,1 \\
\hline $\begin{array}{l}\text { processed } \\
\text { fruits and } \\
\text { vegetables }\end{array}$ & 47,9 & 156,0 \\
\hline
\end{tabular}

special educational institutions have been established to provide agriculture with qualified specialists. However, the implementation of scientific developments created for these objective and subjective reasons is not at the required level. First of all, the obsolescence of the material and technical base of agriculture in the country has a negative impact.

"Today, there are more than 240,000 agricultural machines in the country, including 52,000 tractors. The level of provision of tractors in vegetables and melons - 54\%, horticulture and viticulture $48 \%$, of which $57 \%$ of tractors specializing in horticulture, $41 \%$ of transport tractors, $31 \%$ of driving tractors have reached the end of their service life.

In order to positively address this issue, in accordance with the recently signed resolution of the President "On measures to accelerate the development of agricultural machinery, state support of the agricultural sector with agricultural machinery" in 20192025 in clusters specializing in fruit and vegetable production It is planned to produce and deliver more than 18,744 units of new agricultural machinery, including fruit and vegetable machinery "[2].

Therefore, in the clusters specializing in fruit and vegetable growing in the country, special attention should be paid to providing the industry with modern and innovative equipment. This, in turn, will increase the level of mechanization of the industry, reduce costs and significantly increase productivity due to the timely implementation of agro-technical measures.

The economic growth of the fruit and vegetable sector should be achieved not by further expanding the use of existing domestic resources, but by introducing a system of competitive production cooperation and clusters that meet the modern requirements in terms of product quality.

Another important issue is the issue of specialization of areas that are not given enough attention on the ground. Export enterprises face difficulties and problems due to the lack of information-analytical services that provide consumers with the necessary information about the products grown in the regions.

In addition, the unresolved problems in the field of transport and logistics in the country remain a problem in the preparation, packaging and delivery of products to customers. Considering that by the end of 2019, more than 19.2 million tons of 132 types of agricultural products produced in the country will be exported to 69 foreign countries in pure or processed form, it can be seen that this sector is one of the most 
Doi:https://doi.org/10.37547/tajssei/Volume02Issue08-02

important locomotives of the country's economy.

There are also problems with selection in the country, and it is important to reconsider the varieties of fruits, vegetables and melons, to establish a mechanism to encourage the cultivation of products that do not spoil for a long time, do not lose their quality during storage.

The solution of the above problems will be achieved through the further development of agriculture in the republic, its important branch of fruit and vegetable growing, the growth of the country's economy, the improvement of living conditions of our people.

\section{REFERENCES}

1. "Our main task is to glorify the work of agricultural workers, who are the creators of our livelihood, to raise the development of the industry to a new level" Speech by President Sh. Mirziyoyev at the solemn ceremony dedicated to the Day of Agricultural Workers on December 9 . December 10.

2. "Is there enough equipment for the development of fruit and vegetable growing in Uzbekistan?" People's Speech, August 7, 2019.

3. Decree of the President of the Republic of Uzbekistan dated October 23, 2019 No. PF-5853 "On approval of the Strategy of agricultural development of the Republic of Uzbekistan for 2020-2030".

4. Information from www.stat.uz. 